\title{
Sacred and Profane: Tabooing in Russian Magical Manuscripts of the 17th-18th Centuries (Incantations and Herbals)
}

\author{
Aleksandra B. Ippolitova
}

Citation: Ippolitova, Aleksandra B. 2021. Sacred and Profane: Tabooing in Russian Magical Manuscripts of the 17th-18th Centuries (Incantations and Herbals). Religions 12: 482. https://doi.org/10.3390/rel12070482

Academic Editor: Dennis Ioffe

Received: 24 May 2021

Accepted: 24 June 2021

Published: 28 June 2021

Publisher's Note: MDPI stays neutral with regard to jurisdictional claims in published maps and institutional affiliations.

Copyright: (C) 2021 by the author. Licensee MDPI, Basel, Switzerland. This article is an open access article distributed under the terms and conditions of the Creative Commons Attribution (CC BY) license (https:// creativecommons.org/licenses/by/ $4.0 /)$.
A.M. Gorky Institute of World Literature of the Russian Academy of Sciences, 121069 Moscow, Russia; alhip@yandex.ru

\begin{abstract}
Linguistic taboos (euphemisms, omissions, and other) are an essential part of Slavic verbal and written culture. In this article, we analyze cryptography as a form of tabooing in the magical texts of the grassroots manuscript tradition of the 17th and 18th centuries (handwritten incantations and herbals). Our main objective is trying to see a system behind separate examples and define which kinds of texts are usually tabooed in incantations and herbals, their topics, and messages. We have managed to find out that the function of keeping secrecy is not relevant for the magical tradition; rather, encryption was used to emphasize the elements that are of special importance. In the book of incantations called the Olonets Codex, dating back to the 17th century, ciphering was used for the names and titles of sacred and demonological characters, antagonists, descriptions of certain rituals, closing phrases for the incantations (amen, "key"), etc. We hypothesize that the encryption is used in the Olonets Codex as a means of retaining the magical strength of all the texts in the manuscripts, protecting from hostile beings, sacralizing where necessary, tabooing what was considered sinful for religious reasons, accentuating the main meanings of the incantations, etc. In the herbals, cryptography is basically used for tabooing of "sinful" or trappy topics (love magic, magic used against courts and authorities, some contexts concerning sorcery, jinx, and "secret" knowledge), and in the texts that had to bear sacral meaning (incantations and prayers).
\end{abstract}

Keywords: magic; folklore; Slavic studies; Russian studies; herbals; incantations; manuscript studies

\section{Introduction}

The phenomenon of taboo is one of the cultural universals common to both archaic and modern societies. The term taboo comes from the Polynesian word tabu or tapu. It became known to Europeans through Captain James Cook's journals of 1777 (Allan 2018a, p. 3). English social anthropologist A.R. Radcliffe-Brown so described this phenomenon:

In the languages of Polynesia, the word means simply "to forbid", "forbidden", and can be applied to any sort of prohibition. A rule of etiquette, an order issued by a chief, an injunction to children not to meddle with the possessions of their elders, may all be expressed by the use of the word tabu (Radcliffe-Brown 1939, pp. 5, 6).

An important role in the history of research into the taboo concept belongs to Sir James G. Fraser, who discovered that taboos are characteristic not only for the cultures in the Pacific area, but also for other ancient and modern peoples (Frazer 1888). He examined the phenomenon of taboo in detail in his book "Golden Bough" (3rd ed., Frazer 1911) and proposed classification of taboos into tabooed acts, persons, things, and words.

The book by Dmitry K. Zelenin, a Russian ethnographer, summarizes a lot of information about linguistic taboos in various Eurasian cultures (Zelenin 1929, 1930). The researcher divided the prohibitions into two large groups: those related to trades (hunting, fishing, beekeeping, etc.) and prohibitions in domestic life.

Modern approaches to the problem of linguistic taboo and the corresponding literature are discussed in The Oxford Handbook of Taboo Words and Language (Allan 2018b).

Linguistic taboos are an essential part of Slavic oral and written culture. Russian ethnolinguists Yelena L. Berezovich and Svetlana M. Tolstaya define linguistic taboo as 
"evading calling objects by their principal names or mentioning them in certain situations" (Berezovich and Tolstaya 2012, pp. 224, 225). In folklife culture, it is done, on the one hand, to protect oneself from the danger allegedly coming from the object in question (e.g., a disease, a wild animal, etc.), and on the other hand, to protect something very valuable or sacred (God, a child, a domestic animal, etc.). Additionally, words connected with the body, uncleanness, sexuality and fertility, vices and crimes are also tabooed in some situations (Berezovich and Tolstaya 2012, p. 225).

In oral tradition, taboos can take the form of euphemisms or omissions. Written tradition offers broader opportunities for tabooing. In manuscripts, for example, the presence of taboos can be recognized through edits in the initial text or corrections made in a text subject to translation. Thus, in Russian books dating back to the cusp between the Middle and the Modern Ages, tabooing becomes an issue when dealing with another cultural context, e.g., when European scientific works are translated into Russian. In the 17th-century copies of the Gaerde der Suntheit medical essay (Luebeck 1492), which was translated into Russian in 1534, the aetiological legend of the Morsus diaboli (Succisa pratensis Moench) plant was eliminated because of some mentions of the devil and sorcery (Ippolitova 2018). The late 16th century's Russian version of Liber de arte distillandi (the book about the art of distillation) by the Strassbourg doctor Hieronymus Brunschwig (first ed. 1500) was deliberately missing the medicines based on human blood and feces, angleworms, as well as astrological and esoteric advice (Sapozhnikova 2016, 2019).

Another sign of tabooing in manuscripts can consist in cryptography: certain words or texts are encoded using various ciphers. The main work dedicated to Cyrillic cryptography was written by Mikhail N. Speransky in 1929, offering a plethora of facts about South Slavic and Russian cryptography, the methods of ciphering and deciphering, and some of their functions (1. hiding sensitive information from prying eyes; 2 . hiding the author's name out of Christian humility; 3 . just for fun or as a trick $\left.{ }^{1}\right)$.

As A. Arkhipov further defines the list of functions suggested by Speransky, he mentions that cryptographic tradition is not that rich in texts that hide some sensitive information, and supposes that the main function of cryptography is to emphasize the importance of key points in the text and underscore the "sacral value of personal names or other important elements". Therefore, its use "contained some kind of sacral, sometimes even magical force." (Arkhipov 1980, pp. 85, 86).

In a recent study, D. Bulanin supports Arkhipov's view, mentioning that the array of medieval cryptographic texts does not actually contain anything really "secret"; these are names of sacral concepts and objects, those of writers and other persons, references to the circumstances under which the writing was done, reverential quotes, invocations, and some elements marking the structure of the book. So far, studies of cryptography have mostly been sporadic (enough to say that there has not been any monograph on this topic after Speransky's), with most attention being paid to the deciphering techniques. Although it may seem that cryptographic sources actually yield little information, they are "priceless as a means to take a look on the spiritual world of the early Slavs". That said, Bulanin suggests focusing on the functions of cryptography in written Slavic culture, its intended use, objectives, and the kind of texts that used to be ciphered (Bulanin 2020, pp. 58, 59). This approach is also the methodological basis for our work.

In this article, we intend to analyze cryptography as a form of tabooing in the magical texts of the grassroots manuscript tradition of the 17th and 18th centuries: handwritten incantations and herbals. In those genres, the functioning of cryptography has not been studied in a close manner so far ${ }^{2}$. Our main objective is trying to see a system behind separate examples and define which kind of texts are usually tabooed in incantations and herbals, their topics, and messages.

In our search for incantations, we studied the most extensive collection of texts pertaining to the period in question, A.L. Toporkov's "Russian Incantations from Manuscripts of the period between the 17th and early 19th century" (RZRI 2010). Out of the 36 manuscripts included in this study, four turned out to have encrypted text; however, it was only com- 
plete in one of them, the Olonets Codex of Incantations ${ }^{3}$ dating back to the second quarter of the 17th century. So, we decided to focus our analysis on this collection.

As for the herbals, we have used a significant pool of texts from 17th- and 18thcentury manuscripts collected over many years from archives and libraries of Moscow, St. Petersburg, and other Russian cities.

\section{Cryptography in the Olonets Codex of Incantations, 17th Century}

The Olonets Codex, henceforward the OC, is unique in many ways against the background of handwritten incantation tradition, "unequaled in volume, variety of topics and plots, not only as of the 17th century, but, apparently, in the entire Russian manuscript tradition" (RZRI 2010, p. 37). This is one of the earliest extant incantation books, coming from the Russian North (surroundings of the Onega Lake), and is written in two languages, Russian and Karelian-Veps ${ }^{4}$. It was introduced into research as early as in the second half of the 19th and early in the 20th century (Malinovsky, 1876; Sreznevsky 1913, pp. 481-512), but was only published in full, accompanied by A. Toporkov's extensive comments, in 2010 (RZRI 2010, pp. 37-310). Several linguistic works on the OC, significantly supplementing the ideas about the manuscript, have been written recently by A.S. Alekseeva and A.A. Gippius (Alekseeva 2017, 2018, 2019, 2020; Alekseeva and Gippius 2019).

According to A.L. Toporkov, the OC is written by two persons (texts No. 1-35 and No. 36-125) (RZRI 2010, p. 62). In the first part, only No. 32 is ciphered, while there are six more (No. 48, 58, 104, 107, 109, 124) in the second one ${ }^{5}$. Often, the word «amen» (Russ. аминь) is also ciphered (about 20 cases, all in the second part), as well as the word "key" (Russ. ключ) in the zakrepka ${ }^{6}$ (once, No. 88) (RZRI 2010, pp. 63, 64). All encrypted texts are written in Russian. Both writers used the so-called simple lithorea (Russ. простая литорея), a cipher where each one of the ten consonants of the first half of the alphabet was replaced with the corresponding letter from the other ten consonants but going in reverse order, from the end of the alphabet to its beginning ${ }^{7}$ (Speransky 1929, pp. 97, 98, see Table 1).

Table 1. Simple lithorea cipher (after Speransky 1929, p. 98).

\begin{tabular}{cccccccccc}
\hline$б$ & в & Г & д & ж & з & к & л & м & н \\
\hline$щ$ & ш & ч & ц & $\mathrm{x}$ & $\phi$ & т & $\mathrm{c}$ & $\mathrm{p}$ & п \\
\hline
\end{tabular}

According to A.L. Toporkov, cryptography in the OC "is used in the most doubtful parts, which could have caused much trouble if read by anyone unauthorized" (RZRI 2010, pp. 63, 64). A.A. Turilov and A.V. Chernetsov are also inclined to see cryptography in the incantations as a means to avoid displeasure of the authorities ${ }^{8}$ (for example, researchers believe that the name of Tsar Mikhail Fyodorovich is written with simple lithorea in the OC, "for secrecy") (Turilov and Chernetsov 2002a, p. 71).

As for the Karelian-Veps texts in the Codex, A.A. Turilov and A.V. Chernetsov suggest interpreting them as a secret language of sorcery, a kind of cryptography, too (Turilov and Chernetsov 2002a, p. 71). A.L. Toporkov believes that this hypothesis needs more substantial rationale (RZRI 2010, p. 82).

We believe that the functions of cryptography in the OC are not limited to secrecy (if any at all) but are more complicated and diverse than has been supposed so far.

The functionality of ciphered texts in the OC is various enough. They include incantations about tsars and the authorities (No. 32), cattle release (No. 58), fistfights (No. 104), love spells (No. 107), incantations against snake bites (No. 109), against trees and foes (No. 124), and an incantation to scare mice away from stacked rye ${ }^{9}$ (No. 48). Thus, the incantations can be classified into groups based on their functions and topics: social and interpersonal $(32,104,107)$, protective $(124)$, housekeeping $(48,58)$, and curative (107). This classification is partly conventional, because, say, No. 124 can also be considered a text about social interactions (with foes). The curative incantation (against snakes) stands somewhat apart because it is of Karelian-Veps origin, only its title being written in Russian 
using lithorea ${ }^{10}$. It is important that the distribution of cryptographic texts by function and topic does not correlate with the general distribution of incantations by those groups in the Codex in general ${ }^{11}$ (see Table 2 and Figure 1).

Table 2. Statistic of ciphered Russian incantations in the OC.

\begin{tabular}{|c|c|c|c|c|c|}
\hline & Protective & Curative & Social/Interpersonal & Housekeeping & Total \\
\hline $\begin{array}{l}\text { Overall number of } \\
\text { Russian incantations in } \\
\text { the OC }\end{array}$ & $35(38.5 \%)$ & $33(36.3 \%)$ & $15(16.5 \%)$ & $8(8.8 \%)$ & 91 \\
\hline $\begin{array}{l}\text { Number of ciphered } \\
\text { incantations in the OC }\end{array}$ & $1(16.6 \%)$ & - & $3(50 \%)$ & $2(33.3 \%)$ & 6 \\
\hline $\begin{array}{l}\text { Proportion of ciphered } \\
\text { incantations in each } \\
\text { group }\end{array}$ & 1 of $35(2.9 \%)$ & - & 3 of $15(20 \%)$ & 2 of $8(25 \%)$ & 6 of $91(6.6 \%)$ \\
\hline
\end{tabular}

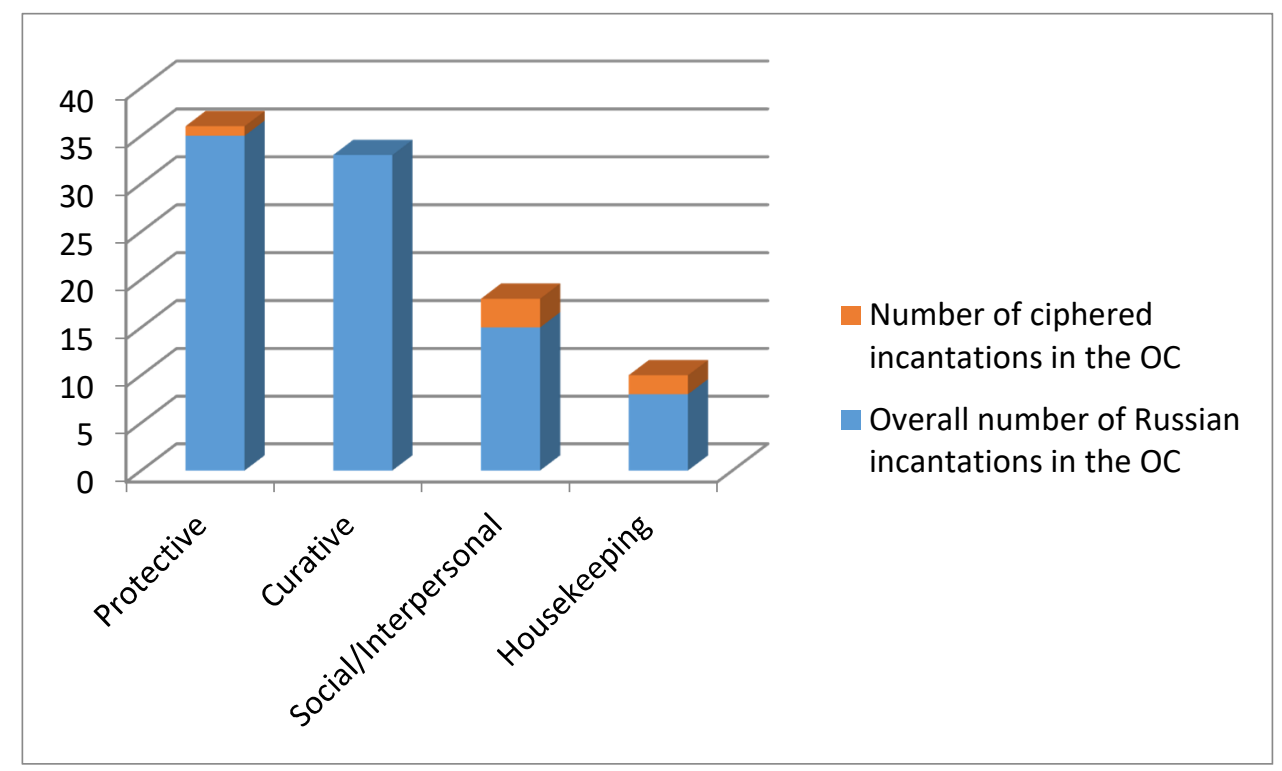

Figure 1. Distribution of ciphered Russian incantations in the OC.

According to the table, half of the incantations containing cryptography belong to the social/interpersonal group (and even two thirds of them if we include No. 124, too), while the remaining third contains household-related incantations. Meanwhile, within the Codex in general these groups are on the third and fourth positions in terms of occurrence. Accordingly, one fifth of the social/interpersonal incantations contains cryptography, as does somewhat about a quarter of the household-related ones.

The texts are encrypted not in their entirety, only some words or phrases therein. There is cryptography both in the titles of the incantations (No. 107, "Слова к женкам"12 ("Words to women"), No. 109 "Слова змеиные" ("Snake words")) and in the instructions to them (No. 48, 58, 104, 124) as well as in the incantations themselves (No. 32, 48, 58, 104, 107,124 , i.e., all of them except for the "snake" one). That means that the incantation about the tsar and the government (No. 32) only has cryptography in the text itself; the snake one (No. 109), in the title only, the love one (No. 107), in the title and in the body, and all the rest (No. 48, 58, 104, and 124) have it both in the texts and in the instructions.

The incantation No. 32 is intended to make all people and authorities like the caster. The name and title of Tsar Mikhail Fyodorovich are mentioned twice, ciphered. First, it goes on about the beauty of the Tsar, which the caster wants to associate with, then about 
the caster's desire to be liked by the Tsar, as well as by the authorities, the higher-ups, and the noblemen.

И как свет сей блистаетца и Христос наряжаетца, свет настал и Христос народис(я) ${ }^{13}$, и как падут утренные и вечерние росы на землю и на во(ду), також бы пала красота и лепота царя и господаря и великого князя Михаила Федоровича всея Руси ${ }^{14}$. < . . $>$ и как любы Господу Исусу Христу свои Б(о)жии престолы, також бы и яз люб был, раб Б(о)жий имярек, кому говориш(ь) имярек, царю, господарю и великому князю имярек всея Руси ${ }^{15}$ и всем властем, и началом, и велльможам. (RZRI 2010, p. 106).

And like this light shines and Christ is adorned, light has shone and Christ is born, and like morning and evening dews fall upon earth and water, so may fall the beauty of Mikhail Fyodorovich, the Tsar and Lord and the Grand Prince of all Russia. < . . > and like Lord Jesus Christ loves His Godly thrones, may also me, servant of God (name), be loved by the one called by the name (name), and also by the Tsar, Lord and Grand Prince (name) of all Russia and by all authorities, higher-ups, and noblemen. (RZRI 2010, p. 106).

The love incantation (No. 107), apart from the title «Слова к женкам» (Words to women), ciphers the name of the mythological Tsar, Zhazhda (Rus. жажда "thirst"), the phrase «во уста» (meaning to the lips of the woman to whom the magic is addressed; a river of fire is meant to enter her lips), and the phrase «сердце у той рабе» (the heart of that woman, God's servant):

Слова к женкам ${ }^{16}$.

На зоре на утренней пойду яз $<\ldots>$ и увижу яз царя Жажду ${ }^{17}$. Цар(ь) Жажда ${ }^{18}$, об(ъ)яви мне огненную реку < . . > пади ты, огненная река, имярек во уста ${ }^{19}$. И как та огненная река горит, так бы горело сердце у той рабе 20 имярек < . . > . (RZRI 2010, p. 132).

Words to women.

In the early dawn will I go $<\ldots>$ and see Tsar Zhazhda. Oh Tsar Zhazhda, show me a river of fire $\langle\ldots>$ may you river of fire fall into the lips of (name of woman). And like that river of fire burns, may the heart of that woman, [God's] servant (name) burn, too $<\ldots .>$. (RZRI 2010, p. 132).

Thus, in addition to the name of Tsar Zhazhda, everything that has to do with the woman (references to her, like женка "woman", раба "(God's) servant", and her body parts, like уста "lips", сердце "heart") is ciphered here.

In the fistfight incantation (No. 104), the names of demonological characters (forest and water spirits, leshy and vodyanoy respectively), whom the caster summons for helping him win, are also ciphered, as is the designation of the opponent, the fistfighter, and all the words referring to the harm done to him: (arms and legs) weakened, (eyes) turned blind, (arm) raise, beat (my enemy). The caster's fists are also mentioned ciphered (evidently as a means of doing harm to the enemy) as well as the pronoun "my" in the phrase "моему супостатаю" («for my enemy»), maybe in order to make him stand out from among the other enemies.

Се яз, раб имярек< .. . > призываю к себе на помощ(ь) из леса лешех, из воды водяных ${ }^{21}$; и вы, из леса лешые, из воды водяные $e^{22}$, подите ко мне на помощ(ь) противо моего супостатая, кулачног (о) бойца ${ }^{23}$, и пособите вы мне побит(ь) $)^{24}$ моего супостатая, кулачного бойца ${ }^{25}$ имярек, своими кулаками ${ }^{26}$. И вы, из леса лешие, из воды водяные 27 , возмите(у) сег(о) имярек мертвеца ${ }^{28}$, камен(ь) и положыте моему супостатаю, кулачному бойцу ${ }^{29}$ имярек, на руки, или на ноги, или на главу; кол(ь) есть сему мертвецу ${ }^{30}$ тяжело от земли и от камени, стол(ь) бы тяжело было моему ${ }^{31}$ супостатаю, кулачному бойцу ${ }^{32}$ имярек, противо меня руки поднят(ь) $)^{33}$, чтоб у моего супостатая кулачног(о) бойца ${ }^{34}$ имярек руки и ноги ослабли ${ }^{35}$ и в глазах слепота ${ }^{36}$ от моего приговора и до моег(о) отговору. (RZRI 2010, pp. 130, 131).

Herewith do I, God's servant (name) < . . > summon for help leshys from the forest and vodyanoys from the waters; so may you, leshys from the forest and vodyanoys from the waters, come to help me against my enemy, fistfighter, and help me beat my enemy, fistfighter (name), with my fists. And you, leshys from the forest and vodyanoys from the waters, take from this 
dead man (name) a stone and put it onto my enemy's, fistfighter (name)'s, arms, or legs, or head; just like earth and stone are heavy for the dead man, so may it also be heavy for my enemy, fistfighter (name), trying to raise his arms against me, and may my enemy, fistfighter (name)'s arms and legs weaken and his eyes turn blind from [the moment of] my incantation and up to [the moment] when I cancel it. (RZRI 2010, pp. 130, 131).

There is also another figure in this incantation, the dead man, whose objective is to make the enemy weaker. The reference to the dead man is ciphered both in the incantation and in the instructions that follow, describing the rite that has to be performed on the dead man's tomb: this is where the incantation is to be read thrice; then the caster bows unto the dead man and takes the stone, putting it into his breeches or his sleeve. Apart from the dead man, the following is also ciphered here: the location (могила "tomb"), the denomination of the incantation itself (слова "words"), the references to the caster's ritual actions (the thing that he takes off $(K)^{37}$ ), the repetition of the incantation (в другой ряд "again"), the bow (поклонися "bow"; да поклонися мер $($ т)вому до земли "and bow unto the dead man to the ground"), the cardinal point where the caster is looking (на север "northward"), and the place where the caster hides the object (в портки, за рукав "into your breeches or behind your sleeve"):

Пришед к могилы ${ }^{38}$, да соими крест ${ }^{39}$ да проговори слова ${ }^{40}$ ряд да поклонися мер $(т)$ вому до земли ${ }^{41}$, а сам зри на север ${ }^{42}$, да в другой ряд ${ }^{43}$ проговор(и) тож, поклонися ${ }^{44}$,

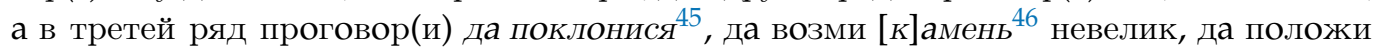
в портки или за рукав ${ }^{47}$. (RZRI 2010, p. 131).

As you come to the tomb, take off your cross and say the words [spell] once and bow unto the dead man to the ground, while looking northward, then again say it, bow, and then the third time say it and bow, and take a small stone, and put it into your breeches or behind your sleeve. (RZRI 2010, p. 131).

The cattle release incantation (No. 58) is meant for protecting the cattle during the forest pasturage season. Such texts used to consist of "three parts. (1) an address to the forest tsar, his wife and children; (2) mentioning of a gift or treat that the caster has brought; (3) the ask to care for the cattle throughout the pasturage season" (RZRI 2010, p. 231). In the instructions for this one, cryptography covers ritual elements, ciphering the location (forest, a hidden place, остров (a higher ground in the forest), выскить (an uprooted tree)) and time (early in the morning before sunrise) of the ritual treatment, as well as the imperative of the action (неси "bring"):

Аще хощеш(ь) скота отпущат(ь) мног(о), и ты щуку свежую да 3 яйца да 3 бочки меду розсыти, да неси в лес на остров (в) укромное место на выскит(ь), а неси поутру рано до солнца ${ }^{48}$. (RZRI 2010, p. 116).

If you want to release a lot of cattle for pasture, then [take] a fresh pike and 3 eggs and 3 barrels of liquid honey and bring it all to a hidden high ground in the forest next to an uprooted tree, and do it early in the morning before sunrise. (RZRI 2010, p. 116).

The incantation No. 58 itself ciphers the address to the lords of the forest, Tsar Gongoy and Tsarina Gogeya, and their children (but their servants are written as usual). Then, certain significant words are also ciphered (обед "dinner"), i.e., the ritual treat, лебеди "swans", which is the metaphorical name for the eggs the caster has brought, and the ask to accept the treat в чести "in honor":

Государь царь Гонгой и царица Гогея, и сынове, и дочери ${ }^{49}$, и слуги, вам обед ${ }^{50}$, щука свежая, да три белые лебеди ${ }^{51}$, да три бочки меду; а приймете в чести ${ }^{52}$, а за то стерегите и берегите и пасите вес(ь) мой скот< . . > (RZRI 2010, p. 116).

Oh you Tsar Gongoy and Tsarina Gogeya, and their sons and daughters and servants, here is a meal for you, a fresh pike and three white swans, and three barrels of honey, too; please accept this in honor, and as a reward protect and observe and care for all my cattle $<\ldots>$. (RZRI 2010, p. 116).

In the incantation No. 124 (against trees and foes), the caster addresses a mythological figure, Tsar Shustiya, asking him to turn his body into stone, his bones into bulat (steel) 
and his ribs into copper, so that he becomes invulnerable to any foes or falling trees. In this case, only some parts of the zakrepka are ciphered:

... слова(м) клю(ч), а древа(м) тле(н), а телу моему креп ${ }^{53}$. Во имя О(т)ца и Сына и Святого Духа. Сим слова(м) ами(н) ${ }^{54}$. (RZRI 2010, p. 143).

... key to the words, and rot to the trees, and strength to my body. In the name of the Father, the Son, and the Holy Spirit. To these words, amen. (RZRI 2010, p. 143).

The instruction No. 124 says that the caster should read the incantation while standing on iron, and the name of the metal is ciphered (however in the second instance it is written in the regular way):

Гово(р) 3(ж), стоя на желизе 55 да на камени, а в рука(х) де(р)жа(т) железо да каме(н), да оче(р)ти(т) собя 3(ж) о(т) утра да до вечера. (RZRI 2010, p. 143).

Tell this three times, standing on iron and on stone, with iron and stone in your hands, and circumscribe yourself, three times from morning to evening. (RZRI 2010, p. 143).

The instruction to the incantation against mice (no. 48) encrypts the action to be done with harvested rye: класть в стог ("stack"). The incantation itself encrypts mice themselves ${ }^{56}$ :

Аще кто хощет рож класти в $(c)_{\text {тог }}^{57}$, и ты возми 9 каменей да 9 жеребейков ол(ь)ховых да положы наперед, а молви: Мышем ${ }^{58}$ камен(ь) то им хлеб, а древо то им волога, за колико лет обновляется круг земный. (RZRI 2010, p. 112).

Should someone want to stack rye, then take nine stones and nine alder rods and put [them] first [i.e., before stacking the rye], and then say: To mice, stone is bread and wood is soup [for so many years], as the earth renews (RZRI 2010, p. 112).

Thus, we have seen that only a few texts $(6.6 \%)$ of the OC actually use cryptography for separate words and phrases. It is worth noticing that in other parts of the same manuscript, the same words or phrases are written in the regular manner. This could be a powerful argument against the earlier version stating that the encryption in the OC (and in other handwritten incantation books, too) was a means to avoid persecution from the authorities. In our mind, should the authors of the OC actually have intended to do so, the encryption would have been more consistent. For instance, all the names of mythical creatures and fragments of "black" incantations would have been ciphered, too.

Therefore, it appears to make more sense that cryptography in the OC was used in approximately the same way as it was in other genres of written texts. That is, as D.M. Bulanin puts it, to emphasize important parts of the text rather than to hide anything "secret" (from intruders or authorities) (Bulanin 2020, pp. 59, 60).

As we have seen, there is an array of characters that appears in the encrypted parts of the OC. These are Tsar Mikhail Fyodorovich (full name and title), some mythical creatures, such as Tsar Zhazhda, Tsar Gongoy, and Tsarina Gogeya and their children, forest and water spirits, a dead man; also, people having to do with the caster: the woman (addressee of the love spell), the fistfighter (enemy of the caster); also, animals (mice or snakes doing harm to the caster).

We believe that Tsar Mikhail Fyodorovich's name is ciphered as a sacred word, which is actually confirmed by various studies (Toporkov 2007, pp. 69-72, 78; Toporkov 2018, pp. $117,118)$. We should note that this name also appears in the Veliky Ustyug incantation book, created at the same time as the OC, and is not ciphered there (Turilov and Chernetsov 2002b, p. 212). The Tsar's name could also have been ciphered in the OC for being perceived as a kind of talisman, so that no one could do harm to the Tsar ${ }^{59}$.

The names of mythical creatures, such as leshys, vodyanoys, the dead man, Tsar Zhazhda, Tsar Gongoy, and Tsarina Gongeya, could have been tabooed out of fear that they could do harm to the caster. Additionally, tsars, even mythical, could be perceived as sacred beings, too ${ }^{60}$.

The names of the caster's "enemies", such as the fistfighter or mice or snakes could have been tabooed so that they would never know what was being planned against them. The ciphered description of such a common thing as stacking rye could also be something 
of this kind: to prevent the mice from knowing. The mentions of women were evidently tabooed in some contexts that had to do with love magic, since it was considered a sin.

Additionally, cryptography in the $\mathrm{OC}$ is used in the cases of using magic against other people, like debilitating a fistfighter or attracting a woman; in both cases, the addressees' body parts are mentioned.

The descriptions of rituals were also encrypted. These are, first, the ritual treats to the lords of the forest: the place and time, the actions themselves, and the treats themselves (обед ("meal"), лебеди ("swans", metaphorical name for eggs), and the ask to receive the meal в чести ("in honor")). Second, the ritual at the dead man's tomb: the ciphering is used for the location, the actions (bowing, facing northward), verbal elements (reference to the incantation (слова ("words"), and their repetitions)), and certain things (breeches, sleeve, cross).

In some cases, cryptography serves to emphasize the basic meaning of the text. For example, in the incantation No. 124 all the encrypted words appear to contribute to one single objective: making the caster invulnerable. They are the zakrepka телу моему креп ("strength to my body"), the second zakrepka with the encrypted аминь ("amen"), and the word железо ("iron") which appears encrypted in the instruction.

\section{Cryptography in the Herbals of the 17th-18th Centuries}

Russian handwritten herbals as a tradition existed from the early 17th to the early 20th century, and this tradition was heterogeneous. The herbals describe plants both real and fictional, intended for use for household, cures, or magic; some plants were said to have supernatural properties (see Ippolitova 2008 for more details). The texts about plants in the herbals have a rather consistent structure: the plant's name, description, where and when it grows, time and ritual of collection, functions, and ways of using.

In the herbals of the 17th-18th centuries, there is cryptography in the texts about 12 plants, which is not that many (about $2 \%$ ) for an array of about 500 plant descriptions, and it is used sporadically as a rule (usually about $1-3$ texts for one plant) ${ }^{61}$.

Here, only some parts of the text are encrypted, from one word to several phrases. In the structure of the articles, the use of cryptography is aligned with the descriptions of the plants' functions (how and what for they are used), to-wit: love magic (5 plants), various kinds of other magic (6 plants), and cure (1 plant). Aside from that, one incantation, two prayers and an unclear fragment (possibly incantation or plant picking ritual) are encoded.

Out of these 12 plants, the majority ( 9 of 12 ) are said to have completely magical functions, while at least 5 are charmful (have an anthropomorphic root; have flowers that burn at night like candles; the plant can destroy iron objects; has 4 or 12 different flowers; the one who finds the herb will get lost and go mad).

There are basically two types of cryptography in the 17th-18th century herbals, popular in Russia back then: simple lithorea and using the initial letters of the words ${ }^{62}$ (sometimes with a complicating twist). There is also an example of ciphering using Latin letters (GIM. Museum coll. No 1226; Speransky 1929, pp. 70-72). For some texts, we failed to detect the type of cryptography and, therefore, to decipher them.

\subsection{The Case of the Semitar Plant}

The texts about the magical herb of Semitar ${ }^{63}$ are interesting in terms of both encryption methods and the specific vocabulary being tabooed. In the 17th-18th century herbals and home cure books in question, there are about fifteen variations of texts about this plant, which has an anthropomorphic root and four flowers of various colors (a Russian mandrake, in its way). The names for Semitar can vary in different manuscripts, e.g., семитар, симтарм, сирман, царь трава сам парамонть, etc. There are encrypted fragments in two texts about Semitar.

In a manuscript dating back to the second quarter of the 18th century (IRLI. Velichko coll. No. 26), there is one of the lengthiest descriptions of Semitar (over 300 words), involving the phytonyms of sirman, pokrik ${ }^{64}$. This one contains a detailed description of 
the "man-root"'s anatomy and explains how it should be used in magic. For instance, it was believed that the root's "head" could help a man get to love his wife. The "right hand" prevented both husband and wife from adultery. The "liver", when cooked in milk, was said to be able to cure sterility. Two fragments of the text dedicated to the use of the magic root are written using simple lithorea.

- The root's "chest" is cut in two and the "heart" is taken out. Then, the instructions to the love magic appear ciphered:

И в том корени велико нутр, как в человеке. И ты сердце вынемши< . . >, и да пить девице ${ }^{65}$, коея восхощеши, или жа[н]ке, и по тебе учнет тужить ${ }^{66}$ (IRLI. Velichko coll. No. 26. Fol. 297. No. 73).

And in that root, there are many entrails, just like in a man. So you take out the heart $\langle\ldots\rangle$ and give it to drink to the girl you might want, or a woman, so [she] will yearn for you. (IRLI. Velichko coll. No. 26. Fol. 297. No. 73).

- It was also suggested to use the magic root for success in trials and with people in general:

Коли хочешь тягатися или на суд ${ }^{67}$, тот корень держать при себе, виноват не будешь ничем, властелином ${ }^{68}$ будешь, учнет тебя любеть, и вси люды учнет теба любить зело ${ }^{69}$. (IRLI. Velichko coll. No. 26. Fol. 297v. No. 73).

Should you want to go to court, take this root with you so you will not be guilty of nothing, you will be governor, and also loved, and all the people will love you a lot. (IRLI. Velichko coll. No. 26. Fol. 297v. No. 73).

Thus, the sirman text taboos phrases related to love magic, as well as the magical impact of the caster over other people's feelings and over court, too. At the same time, the words related to marriage magic (to make a husband love his wife, to prevent adultery) and to the magical ability for a woman to become pregnant using the "liver" of the root remain unciphered in the same text.

In the text about the simtarm herb, titled "Should one want to get married" and included into a herbal of the late 17th century, cryptography is used in about the same manner as in the sirman example. A.A. Turilov, the first publisher of this text, suggested a partial reading of this encryption (Turilov 1998) and noticed that it employed various ciphering methods (Turilov 2002, p. 375).

И выняти из того человека сердце: есть бо нутр в том человеке, как в жи[во]м же. И половину того же сердца или третюю часть истерти мизиным пальцом и дать кому ни буди пити ли дв ко а х. ш з с $\sigma^{70}$ ино д十 и ж к возждеют хотя б буди $c^{r}$ или knzna и они $\sigma^{71}$ твои, аще испиеть ис твоих рук. (GIM. Museum coll. No. 1226. Fol. 204r-204v).

Indeed, there is a mixed-up ciphering technique here, based on one or two first letters of a word (sometimes also the last letter and the one prior to it), and based on the Latin alphabet. Based on A.A. Turilov's findings and on our own collation of the text with the original of the manuscript, we suggest our own version of a deciphered fragment.

... и дать кому ни буди пити [женке и]ли де[вке], ко[е]а х[още]ш з[а] с[е]б[я], ино де[вка] и ж[ен]к[а] возжде[ле]ют, хотя б буди ц[а]р[евна] или кн[я]жна, и они б[удут] твои, аще испиеть ис твоих рук.

And take the heart out of that man, for he has entrails, just like a real man does. Then crumble a half or a third of that heart with your little finger and give someone to drink, [to a woman] or a girl you want to possess, then the girl and the woman will yearn, no matter if they are a tsarevna or a princess, and they will be yours if only they drink [the potion] from your hands. (GIM. Museum coll. No. 1226. Fol. 204r-204v)

In this fragment, encryption is used to refer to the women (woman, girl, tsarevna (tsar's daughter), princess), for the phrase that describes which women is it about (" ... you want to possess") and the verb "will be" which confirms that the magical procedure does work.

It is notable that in the texts about Semitar ciphered fragments are not repeated in various texts, i.e., they were ciphered independently, at the discretion of the specific writer. 
There is also a special version of the Semitar text that contains no encryption but has appeared as a result of the "profane" being tabooed. It has no mentions of love or marriage magic (except for childbirth); the folk chrononym of Иванов день (Ivan's day) is replaced with the canonical Рождество Иоанна Предтечи (The Nativity of John the Forerunner); the description of the collection ritual requires the caster to read a prayer and to be clean from any filthiness; the magical function involving the use of the "heart" is replaced with the curing one: to have a wash with the "heart" of the root in order to cure one's own heart. In other words, this text was edited in the tideway of the Christian tradition and religious motives (handwritten cure book of the 17th century, GIM. Uvarov coll. No. 114. Fol. 15v-16r).

\subsection{Love Magic}

In a 1703 text about the Khorobrets herb (Figure 2), there are three words ciphered by simple lithorea and also three letters under titlos in the end:

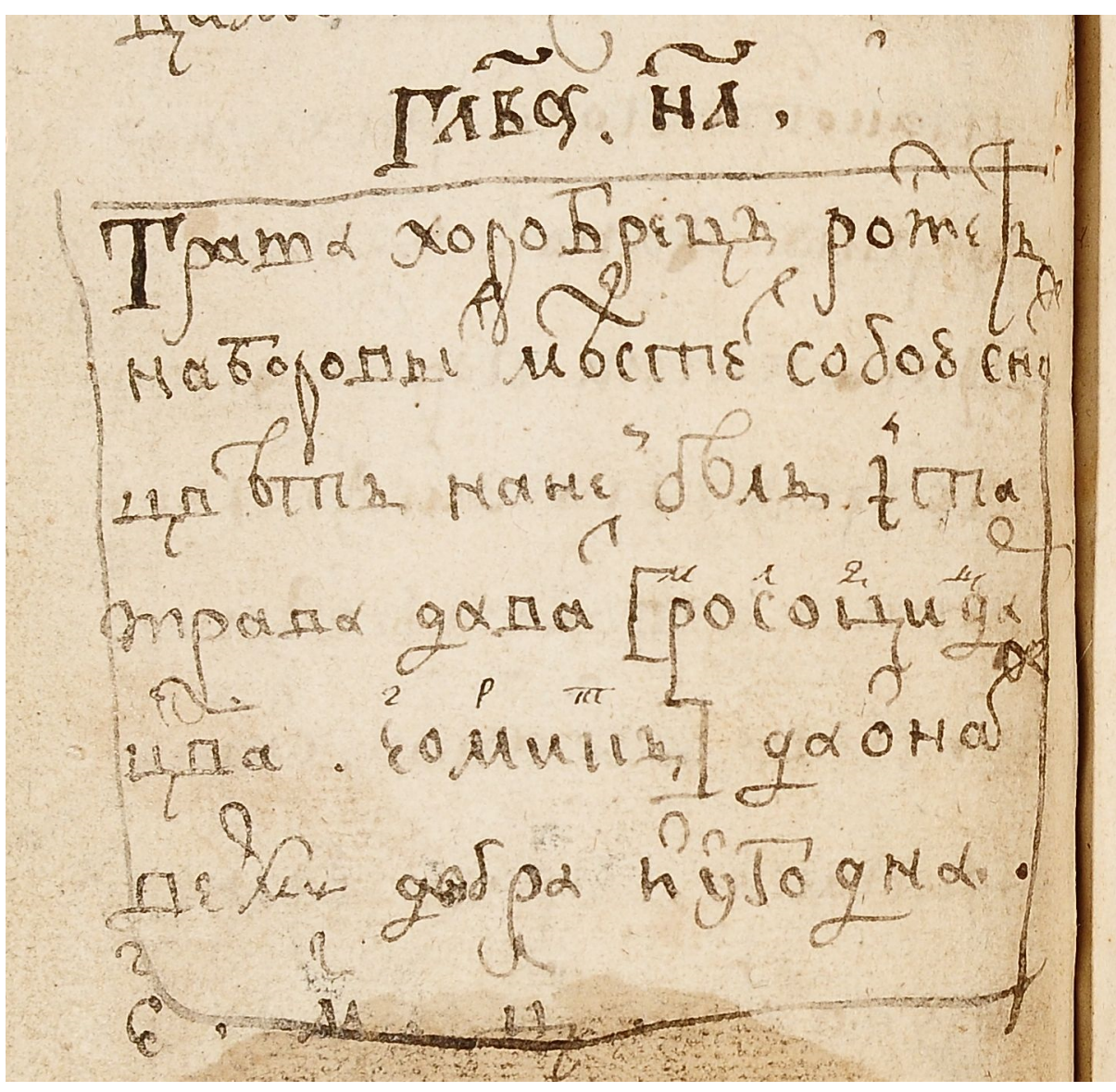

Figure 2. Text about Khorobrets plant with cryptogram, 1703 (RGB. Undolsky coll. No. 1072. Fol. 28v. No. 51).

Трава хоробрец< . . > И та трава давать $\left\{\mathrm{p}^{\mathrm{M}}\right.$ ос $^{\mathrm{J}}$ оц $^{\mathrm{I}}$ ид ${ }^{\mathrm{L}} \mathrm{a}^{\mathrm{p}} ц в а ч^{\mathrm{\Gamma}}$ ом$^{\mathrm{p}}$ ик $\left.^{\mathrm{T}}\right\}$, да она ж

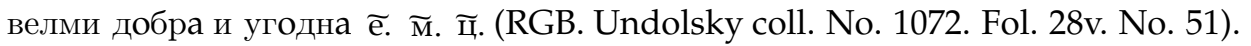

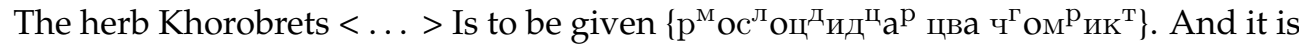
very good and useful indeed. е. $\widetilde{\mathrm{M}}$. $\widetilde{ц}$.

The meanings of the consonants are inscribed over them in the first cryptogram, perhaps by a reader from the 18th century. When deciphered, the text looks as follows:

И та трава давать молодицам ${ }^{72}$ - душа горит.

And that herb be given to young women-soul burns. 
Here, encryption is added at the discretion of the writer, since the same phrase does not appear encrypted in other texts about the same plant. This text is about using magic to make a woman love the caster ${ }^{73}$.

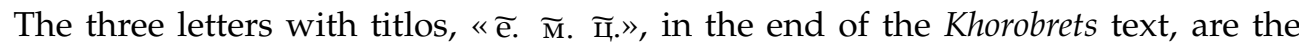
initial letters of the encrypted text's words. In such cases, deciphering is made easier based on versions of the same text in different manuscripts, which sometimes contain unciphered words. One case of this is the text about the Peresyanka plant (18th century), where references to women and girls appear both ciphered and not (see Table 3).

Table 3. Texts about the Peresyanka plant.

\begin{tabular}{cc}
\hline GIM. Uvarov coll. No. 705. Fol. 26. No 79 & BAN. 45.8.175. Fol. 12r. No 76 \\
\hline $\begin{array}{c}\text { Кто ея корень носит при себе, и того } \\
\text { человека любят \{ж и д\}. }\end{array}$ & $\begin{array}{c}\text { Тот корень кто носит при себе, и того } \\
\text { человека любят женки и девки. }\end{array}$ \\
\hline $\begin{array}{c}\text { The one who wears the root [of this plant] is } \\
\text { loved by \{ж и д\}. }\end{array}$ & $\begin{array}{c}\text { The one who wears the root is loved by women } \\
\text { and girls. }\end{array}$ \\
\hline
\end{tabular}

Another trouble when deciphering this kind of encryption is that the scribes sometimes misinterpreted the texts they did not understand, replacing some letters with other ones (usually looking similar).

We again meet references to молодые молодицы (young moloditsas) and encryption in three texts from the 18th century dedicated to the Gnida plant: black, not tall, with a black flower, known to protect from bears (who neither attack nor roar) and from dogs (who don't bark):

Трава гнида $<\ldots>$ Да угодна и молодым молодицам (д) (ж) (ц) (к) (с) (RGB. Museum coll. No. 9530. Fol. 29. No. 76).

Gnida herb $<\ldots>$ Also good for young moloditsas (д) (ж) (ц) (к) (с).

We can suppose that the first letters of the encrypted text, Д and $K$, can have the close meaning as молодицы, i.e., girls and women. In all probability, this text is about love magic, too.

\subsection{Other Magical Functions}

The rest of the examples speaking about plants' functions is encrypted by their first letters and usually not deciphered, the context being reconstructed based on the surrounding words. Let us take a brief look at some examples.

In the text about the Palochnik plant (Typha latifolia L.), encryption “(м) (п) (е)" closes the statement that it is good for millers at their mills (RGB. Museum coll. No. 9530. Fol. 28. No. 72). Meanwhile, the encryption in the text about the magical Sova 1 plant is probably related to the destruction of a mill:

Кто на ту траву наидет - заблудитца, а кто вырвет - без ума будет, а в мелницу кинет - мелницу рознесет п д б з е р ж ч железо д. (IRLI. V.M. Perets coll. No. 489. Fol. 4 v. No. 38).

The one who steps on this herb, will get lost, and the one who pulls it by the roots, will go mad, and when thrown into a mill, it destroys the mill п д бз е р ж ч iron д. (IRLI. V.M. Perets coll. No. 489. Fol. 4v. No 38).

Among peasants, millers were reputed sorcerers, hobnobbing with vodyanoys (water spirits) and leshys (forest spirits). In case of a conflict with a miller, peasants tried to destroy the stanch or even the mill itself (Shchepanskaia 2001, pp. 17-19).

In the copy of the herbal from a 1770 investigation report, there is a text about the magic herb of Muravey (Rus. муравей "ant") that breaks scythes, frees horses from hopples and opens locks. Thanks to the abundance of texts about Muravey, we had no problem deciphering the П: У: fragment: these letters mean петля удавить ("loop strangle"), i.e., this plant could save someone sentenced to hanging from being strangled with a rope (see Table 4). 
Table 4. Texts about the Muravey plant.

\begin{tabular}{cc}
\hline $\begin{array}{c}\text { (Mihajlova 2003, p. 272) (RGIA. F. 796. Op. } \\
\text { 51. D. 322) }\end{array}$ & BAN. 33.14.11. Fol. 35v. No 78 \\
\hline $\begin{array}{c}\text { А в рот положить-не может ево: причем } \\
\text { под титлами поставлены в клетках два } \\
\text { слова П: У: }\end{array}$ & А кто в рот положит, и петля удавить не \\
может. \\
$\begin{array}{c}\text { Put [this herb] into your mouth and can't him: } \\
\text { there are two П: У: } \begin{array}{c}\text { Уords under the titlos in } \\
\text { the cells. }\end{array}\end{array}$ \\
$\begin{array}{c}\text { Put [this herb] into your mouth and no loop } \\
\text { will strangle you. }\end{array}$ \\
\hline
\end{tabular}

In several texts about the Myshka (Rus. мышка "mouse") plant, there is encryption looking like this: д. в. х. к./д в х/ЖK: I: E: Д: В: X:, which correlates with the words хмель (hop plant or drunkenness) and пьет (drinks) (RGB. Dolgov coll. No. 111. Fol. 1; RNB. Q.VI.18. Fol. 38v. No 68; Mihajlova 2003, p. 272: RGIA. F.796. Op. 51. D. 322). Other versions of texts about Myshka make us think that this plant was helpful for quitting drinking.

The magic plant Levuppa, as the herbals put it, cannot be found during the day, but at night its flowers burn like candles, and the other plants bow unto it. Levuppa was said to have some charmful properties: its owner was given honors, it also protected from jinx and foes, at weddings and feasts, and also helped in hunting. In some manuscripts, the plant's functions are not listed in detail but mentioned as a whole: "ко всячине добра" ("[it] is good for everything"), followed by a cryptogram of $4-5$ letters, e.g., з $p$ с т (BAN. 33.14.11. Fol. 32v, No. 70), possibly standing for a description of some specific properties of the plant.

\subsection{Incantations and Prayers in the Herbals}

We can only be sure about the presence of an encrypted incantation in the herbals in the case of one plant, Ulik. There are four texts from the 18th century about it, two of them containing encryption by initial letters of the words; in two others, the entire text of the incantation for the collection of that plant is encrypted. It should be said that the letters in the two ciphers only coincide partially, and the compliance between the incantation and its encryptions is obviously incomplete. Perhaps both encrypted texts have been corrupted during copying. The incantation had to be read while collecting the plant, and its effect consisted in restoring conjugal love. Let us quote the encrypted and the regular versions (see Table 5).

Table 5. Texts about the Ulik plant.

$\begin{array}{cc}\text { Kizhi Museum. KP-4281/1. Fol. 25. No. 78. } & \text { GIM. A.S. Uvarov coll. No. 705. Fol. 28v. No. } \\ \mathbf{8 6 .}\end{array}$

Just like you т: г: п: sо п т к оr м: to own head

Just like you, the herb, have inclined your head toward the ground, let also them incline their с в д: и р: с д ни от х: в: п д: д:. heads toward one another, with all their souls and passionate hearts, reflections and thoughts, readily, forever as long as they live.

In one ciphered incantation about Ulik, the plant's function is different: instead of marital magic, it should be used for attracting maids and women (DTYuS 1998, p. 434).

In some texts about Solneshnik plant, there is a rather large encrypted passage, of about 30 symbols, and it has not been deciphered so far. The text appears to have been 
ciphered by first letters or using a mixed-up method, by the numeric values of the letters. Some letters can differ from manuscript to manuscript, however there are coincidences, too. The encrypted part appears following the phrase that extracting this plant is "not easy"; this latter expression has a special meaning in the herbals, to-wit, having special magic skills; here, those skills consist in knowing which ritual to perform while collecting the plant.

Есть трава солнешник< . . > А копать ея не просто: м.н.о.а.а.о.п.р.p.х. | । .л.л.н.о.п.ж. p.p.p.a.a.s.a. дух. ч.н.н.о. И носить на себе, тот будет силен велми храбр воин. А копать в маие месяце в 9-м числе. А как пропустишь, и ты на Иванов день Купалницы, и никому не сказывай, то велми богат будешь. (RNB. Q.VI.18. Fol. 35v. No. 50).

There is a herb called Solneshnik. < . > And it is not easy to extract: м.н.о.a.a.о.п.p.p.x.। । .л.л.н.о.п.ж.p.p.p.a.a.s.a. spirit. ч.н.н.о. And to be carried with yourself, to become a very brave and valiant warrior. Dig it out on the ninth day of the month of May. If you miss that, do <dig it out $>$ on St. John's day, [after St. Agrippina's day], and tell no one, then you will be very rich. (RNB. Q.VI.18. Fol. 35v. No. 50).

One could suppose that the cryptogram contains an incantation to be read while digging the plant out, or just a description of the collecting ritual. It should be noted that in an 18th century manuscript from RGB, the cryptogram and the words непросто и ("not easy and"), directly preceding it, were deliberately crossed out from the text (RGB. Museum coll. No. 9530. Fol. 26r. No. 65). This is a particular situation when something tabooed is tabooed additionally.

There are also two cases when prayers are also written with encryption. An 18th century manuscript advised to say the Trisagion prayer, ciphered by its first letters, while collecting the above-mentioned herb of Sova 1:

... а рвать непростому С(вятый) Б(оже) С (вятый) К(репкий) С(вятый) Б(ессмертный) П(омилуй) Н(ас) ав (GIM. Barsov coll. No 2257; quoted in: Strakhova 1988, p. 42).

... and collecting is not easy: Holy God, Holy Mighty, Holy Immortal, have mercy on us (thrice). (GIM. Barsov coll. No 2257; quoted in: Strakhova 1988, p. 42).

While collecting the Bogorodichnaya herb (i.e., belonging to Virgin Mary), a prayer to Virgin Mary should be said:

Есть трава Богородичная ... та трава добра человеком и скотом и у которыя жонки болят груди или титки парь да хлебай да говори Б(огородице) Д(ево) ... (GIM. Barsov coll. No 2257; quoted in: Strakhova 1988, p. 42).

There is also the Bogorodichnaya plant, which is good for both people and cattle, and if a woman's breasts ache, [apply it hot] and drink it and say the Virgin Mary [prayer] ... (GIM. Barsov coll. No 2257; quoted in: Strakhova 1988, p. 42).

Thus, there are actually not that many encrypted texts in the herbals (just about $2 \%$ of the plants) but they are not distributed uniformly. Ciphering was used for fragments of texts about the plants, the incantations and prayers included therein; there are various types of encryption; there are also entries that can and cannot be deciphered; the encryption is mainly used in some specific texts about one plant (apparently at the discretion of the writer of each manuscript in particular).

For 7 of 12 plants, encrypted texts have been deciphered successfully. The majority (4) of them have to do with love magic. In such texts, the encryption covers references to women (женка "woman", девка "girl", княжна "princess", царевна "tsarevna", молодица "young woman"), verbs and phrases that express love desires and emotions (восхотеть and хотеть "start yearning for", тужить "long for", душа горит "soul burns"), and the text of the love incantation is ciphered almost in full.

As for social magic, i.e., related to courts, authorities, and people in general, there is only one deciphered fragment (Semitar). This is somewhat related to delinquent, secret knowledge, expressed in the fragment about the rope that will not strangle you (Muravey).

As for the four plants with undeciphered descriptions, we can barely make guesses about their meanings based on the adjacent phrases. As far as we can understand, these parts keep discussing love magic (Gnida), secret knowledge and sorcery (the mill and its 
destruction, Palochnik and Sova 1), plus the motif of quitting drinking (Myshka) and the multi-purpose plant (Levuppa).

The use of encryption in incantations and prayers (three plants deciphered and one not) apparently marked them as sacral texts, simultaneously making them stronger. Importantly, unlike in the incantation books, herbals include such entries encrypted in their entirety, i.e., they are emphasized against the background of the regular text. This could have something in common with the prohibition on saying the incantations aloud in the presence of outsiders, or giving them to outsiders, to prevent these texts from losing their powers (Tolstaya 1999, pp. 240, 241).

\section{Conclusions}

In this article, we have studied the practice of tabooing in handwritten magical texts of the 17th-18th centuries (herbals and incantation books), performed by means of cryptography. Our main idea is that there is some kind of system behind the seemingly unrelated fragments of the manuscripts, even if such a system is not clearly seen now. Let us share some insights.

We believe that in the materials we have studied cryptography is not used for the purpose of secrecy ${ }^{74}$ but rather to emphasize some parts of the texts that appear to be of special value. The most complicated thing here is to understand the nature of this value.

The encryption in the OC is more complicated and diverse than in the herbals, and has a wider functionality, too. In the OC, encryption has to do with the relationships between the caster and various aspects of reality and the magical world. The caster is surrounded and affected by real persons (men and women, authorities, foes), animals (mice, snakes), and demons; they also perform ritual actions in special, hidden places (forest, tomb) using various objects. In each specific case, encryption in the OC has its own function: acting as a talisman for the caster and their possessions, protecting them from foes; as a means to sacralize the figure of the tsar; as a means of tabooing of sinful passions, etc. At the same time, the presence of encryption was meant to make the incantation stronger. Thus, encryption is an instrument to make the incantations multidimensional and complicated, strengthening the existing narratives and adding new ones.

The incantations from the OC were definitely intended for verbal use, i.e., for being read out (whispering or hushfully, but read out anyway, not silently). How did one have to handle the ciphered parts, then? Most probably, the cryptograms were intended for written texts only; the words were deciphered before being read out. Thus, the encryption served as a kind of container for words of special value, to prevent them from "escaping" ahead of time and thereby losing their strength, as it can happen with incantations that are disclosed to outsiders. Let us recall that the word amen is ciphered about 20 times in different parts of the OC, plus the word key one more time. We could suppose that these words served as a kind of zakrepka for the entire book, holding together the magical force of the incantations contained therein ${ }^{75}$. This is similar to the evidence of a sorceress from the Pomorye (Northern Russia) area. In the 1930s, she told a folklore researcher the text of an incantation but not the ключевые слова (Rus. "key words", i.e., zakrepka), to prevent the incantation from losing its effect:

... then come some key words, but the sorceress did not tell them to me. She said, 'I can only disclose those key words in my dying hour, to the one who would take up my trade'. (RGALI. F. 1489. Op. 1. D. 24. Fol. 80).

The same function was probably ascribed not only to the amens but also to all the encrypted texts in the OC. It could well be that the owner of the OC had to teach their successors in trade to read simple lithorea, in order to be able to make good use of the incantations.

Understanding the encrypted parts as the "key words" of the entire manuscript can explain the sporadic use of ciphers in the incantations (and not only there), which appears strange to a modern person. This includes the situations when some important word is only ciphered once or twice, and then is written in the regular manner further on (e.g., 
dead man, tsars of different names, iron). Apparently, it was enough to encrypt the word once to give it all the necessary sacral and magical functions.

The functions of ciphers in herbals appear to be less complicated. In this case, they are mostly used for tabooing sensitive topics (love magic, magic related to courts and authorities, some contexts related to sorcery, black magic, "secret" knowledge), and to mark verbal texts that should have sacral effects (incantations and prayers). It could well be that in the latter case, just like in the OC, cryptography was simply believed to strengthen a text's magical effect and at the same time to protect it from outsiders. Still, almost a half of the encrypted parts of the herbals still remains ciphered; hence, the complete picture could well look less complicated than it really was.

We believe we could further focus on studying the functions of the ciphers, involving more and more sources (published and archived incantation books ${ }^{76}$ and handwritten cure books) and also by expanding their chronology toward the 19th and the early 20th century, a period of transformation in the magical handwritten tradition (Ippolitova 2008, p. 16; RZRI 2010, p. 21). This would mean a very different nature of the encryptions (e.g., herbals include encrypted jokes and phytonyms). Such a study could enable us to perform comparative research of similar genres in other Slavic and, widely, European manuscript traditions. (Important observations in the field of functional study of cryptography from the Middle Ages and early modern times have been made recently, in particular for the German and Hungarian traditions, which opens up the possibility for cross-cultural research: Müller 2014; Láng 2015, 2018). Then, we could study other methods of tabooing in magical manuscripts, such as omissions, euphemisms, and traces of tabooing in edited texts.

Funding: This work was funded by RUSSIAN FOUNDATION FOR BASIC RESEARCH, grant number 20-012-00117.

Institutional Review Board Statement: Not applicable.

Informed Consent Statement: Not applicable.

Acknowledgments: The author is sincerely grateful to this Special Issue guest editor, Denis Ioffe, for inviting to contribute to it.

Conflicts of Interest: The author declares no conflict of interest.

$\begin{array}{ll}\text { Abbreviations } & \\ \text { BAN } & \begin{array}{l}\text { Manuscript Department of the Russian Academy of Sciences Library in } \\ \text { St Petersburg } \\ \text { GIM }\end{array} \\ \text { Kizhi Museum } & \begin{array}{l}\text { Kizhi State Open Air Museum of History, Architecture and Ethnography } \\ \text { in Petrozavodsk }\end{array} \\ \text { IRLI } & \begin{array}{l}\text { Drevlekhranilishche im. V.I. Malyshev of the Institute of Russian Literature of } \\ \text { Russian Academy of Sciences in St Petersburg }\end{array} \\ \text { RGALI } & \text { Russian State Archive for Literature and Art in Moscow } \\ \text { RGB } & \text { Russian State Library } \\ \text { RGIA } & \text { Russian State Historical Archive } \\ \text { RNB } & \text { Manuscript Department of the National Library of Russia in St Petersburg }\end{array}$




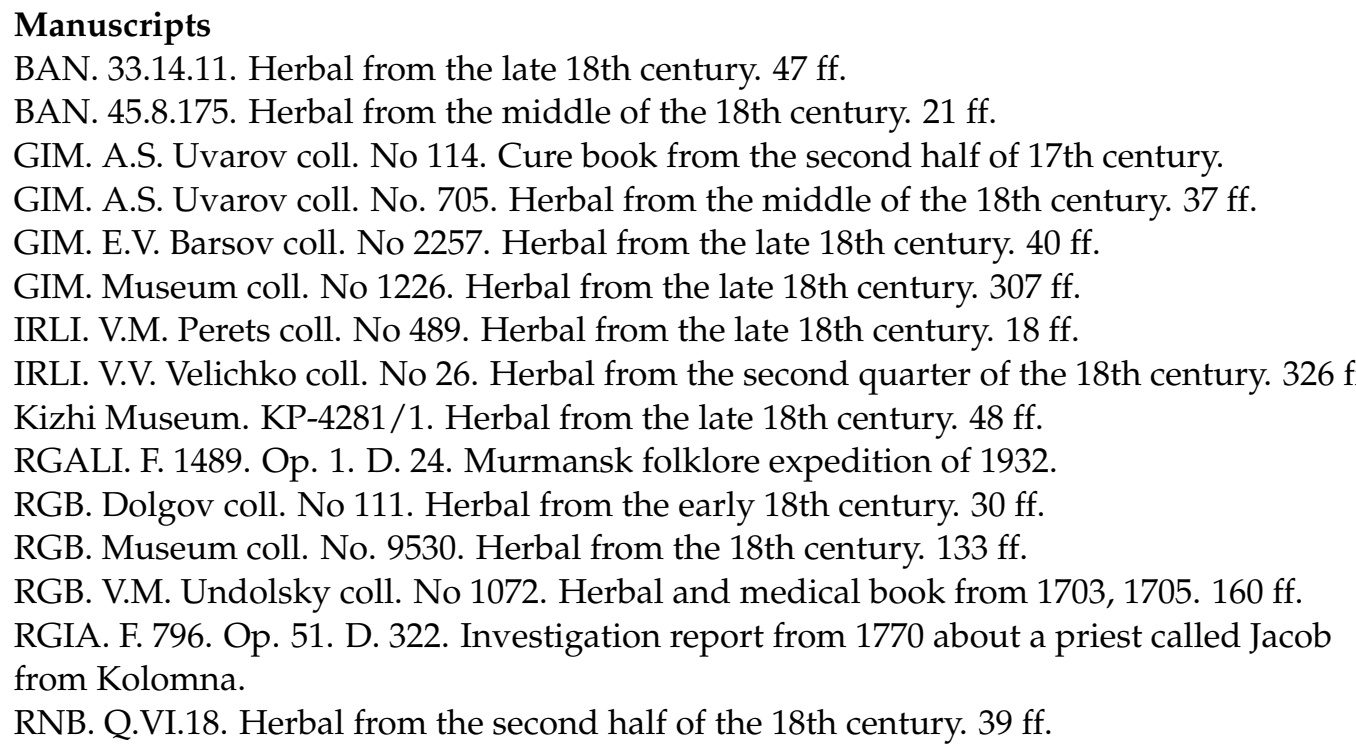

\section{Notes}

Apart from that, Speransky mentions letter strings in incantations as a kind of cryptography (Speransky 1929, p. 3).

A.A. Arkhipov also planned to take on this question (Arkhipov 1980, p. 86), however, in the next edition of his work he limited himself to emphasizing the need for such a study (Arkhipov 1995, p. 145).

3 Today it belongs to the Manuscript Department of the Russian Academy of Sciences Library in St Petersburg (no. 21.9.10).

4 According to A.L. Toporkov's calculations, the OC contains 130 texts, including 90 Russian and 9 Karelian-Veps incantations, as well as "prigovors" (short ritual-magical texts), non-canonical prayers, and texts without verbal magic (RZRI 2010, pp. 48, 75-77).

5 A.S. Alekseeva and A.A. Gippius have supposed that the words вомр and вомра in the love incantation No. 122 are written, "using a special cipher where letters are replaced with the ones most similar to them in shape: $\mathrm{B}$ for $\mathrm{B}, \mathrm{K}$ for $\mathrm{M}, \mathrm{b}$ for $\mathrm{P}$, and therefore mean божий, божья (God's). < . > The attribute preposition, unusual for the phrase раб Божий (God's servant), could also be a form of distortion, a kind of "anti-behavior", according to B.A. Uspensky, caused by the fact that using God's name in an erotic text would have been a blasphemy" (Alekseeva and Gippius 2019, pp. 153, 154). We will not talk about this text herein, since deciphering is still hypothetical.

6 Zakrepka (from Russ. закреплять "to anchor, to fix")—Russian term for final element of incantation, magically "locking" the action of the entire previous text, that gives the words power and neutralizing possible mistakes made in it (Yudin 1997, p. 9).

As A.A. Arkhipov puts it, this kind of cipher is borrowed from the Jewish tradition (Arkhipov 1980).

In the 17th and 18th centuries, sorcery and incantations in Russia were strictly persecuted by church and state, with legal action taken against people owning "incantation books" (Lavrov 2000; Smilianskaya 2003; Kivelson 2013; Mihajlova 2018).

In the 2010 publication, the text is called "so that mice don't eat the straw" (RZRI 2010, p. 112). However, the text itself has not a single reference to straw (and mice don't actually eat it), so we have corrected the name.

The statistics regarding the functional distribution of Karelian-Veps texts is not given in RZRI 2010 (maybe because it is often hard to define).

11 The information on the frequency of Russian incantations in the Olonets Codex is taken from (RZRI 2010, p. 80) but we have also added the mice one (No. 48) to the statistics.

In the original text: надодис.

In the original text: дамя и чолноцамя и шесикочо тпяфа Рижаиса Зецомошига шлея Мули.

In the original text: д(а)рю, чолноцаму и шелитору тпяфю имяреквлея Мули.

In the original text: $т$ хептар.

In the original text: Хахцу.

In the original text: Хахца.

In the original text: шо улка.

In the original text: лемцде у кой маще.

In the original text: иф села севеж, иф шоцы шоцацы.

In the original text: иф села севые, иф шоцы шоцяпые. 
In the original text: тусагпоч(o) щойда.

In the original text: нощик.

In the original text: тусагпоч(o) щоида.

In the original text: ту сатари.

In the original text: иф села севые, иф шоцы шоцяпые.

In the original text: ремкшеда.

In the original text: тусачпору щойду.

In the original text: ремкшеду.

In the original text: роерy.

In the original text: тусагпою щойду.

In the original text: ноцпяк.

In the original text: тусачпочо щойда.

In the original text: олсащли.

In the original text: лсенока.

A.L. Toporkov believes that it could be a garment (cap, caftan, etc.) (RZRI 2010, p. 131). A. Alekseeva and A.A. Gippius believe that it is about the baptismal cross (Alekseeva and Gippius 2019, p. 152).

In the original text: т рочисы.

In the original text: $K$.

In the original text: лсоша.

In the original text: ца нотсопиля ремшору цо ферси.

In the original text: па лешем.

In the original text: ш цмучой мяц.

In the original text: нотсопиля.

In the original text: ца нотсопися.

In the original text: [т]ареп (reading according to: (Alekseeva and Gippius 2019, p. 152)).

In the original text: в номкти или фа мутав.

In the original text: пели ш сел па олкмош в утморпое место па шылтик, а пели ноукму мапо цо лоспда.

In the original text: дапь Чопчой и дамида Чочея, и лыпоше, и цогеми.

In the original text: ощец.

In the original text: сещеци.

In the original text: ш гелки.

In the original text: кесу роеру тмен.

In the original text: ари(п).

In the original text: па хесифе.

Strictly speaking, the word мышем cannot be the beginning of the incantation but instead the last word of the instruction. See also: (Alekseeva and Gippius 2019, p. 146).

In the original text: тсалки ш коч.

In the original text: рывер.

Compare D.M. Bulanin's supposition that the encrypted text on the Zvenigorod bell could have included the name of Tsar Aleksey Mikhailovich so that no devilish forces could harm the Tsar (Bulanin 2020, p. 60; concerning the inscription, see: (Speransky 1929, pp. 94-97, 112, 113)). Regarding the Tsar as a sacred figure, see (Uspensky 1998; Lukin 2000; Toporkov 2007).

However, there are other Tsars mentioned in the OC (Tsar Parfey, Tsar Shustiya, etc.) and their names remain unencrypted. (See (Toporkov 2007, 2018) for more information).

Only in the text about the Solneshnik plant is cryptography indeed used in most texts.

In the absence of additional information, such texts usually cannot be deciphered (Speransky 1929, pp. 41, 42).

Hereinafter, the herbal's phytonym written in regular will refer to the entire array of textually similar texts about the same plant (referred to using one of the most frequent phytonyms that appears in the aforesaid array). The phytonym written in italic will refer to the name of a plant that appears in a specific manuscript.

Compare Polish pokrzyk for "Atropa belladonna L.".

Corrected. Otherwise, it is written цувеце when deciphered, probably because of the writer's mistake.

In the original text: душеде тоея шолкобеви иси хате, и но кеще угпек кухикь. 
In the original text: кячакиля или па луц.

Corrected. Otherwise, it is written бастелином when deciphered, probably because of the writer's mistake.

In the original text: шипошак не будешь нимет, щалкесипор будешь, учнет тебя сющекь и шли сюды учнет неща сющикь зело.

Could also be read as $e$ or $\hbar$.

Letter 5 appears ringed.

In the 18th century, the word молодица (moloditsa) was used to refer to a young woman, usually married (SRYa 18 veka 2003 , p. 10).

Such formulas with the "love burning" motif are popular in Russian incantations and literary tradition, too (Toporkov 2005, pp. 24-45).

It should be said that encrypted manuscripts often attracted the attention of criminal investigators. Thus, a herbal was confiscated in 1770 from a priest called Jacob and some parts of it were copied into the investigation report, including the ones that were ciphered by the initial letters. The investigators left the following note next to one of the encrypted fragments: " ... there are certain letters written from the cells, apparently as explanation for that [text] or some kind of incantation, but the meaning thereof remains unknown" (Mihajlova 2003, p. 270; RGIA. F.796. Op. 51. D.322).

About magical power of zakrepka, see also (Levkievskaya 2002, p. 245).

There are also a lot of encrypted texts in an 18th century manuscript containing some incantations and a herbal (Vinogradov 1909, pp. 28-41), and in the incantations from a 17th century cure book (Pushkarev 1977, pp. 87, 103, 104, 111, 114, 121).

\section{References}

Alekseeva, Alina S. 2017. O dvukh zagadkakh Oloneckogo sbornika [About two riddles of the Olonets codex]. In Antropologiya. Fol'kloristika. Sociolingvistika (Sankt-Peterburg, 23-25 marta 2017). Sankt-Peterburg: EUSpb, pp. 4-7.

Alekseeva, Alina S. 2018. Tri kommentariya k Oloneckomu sborniku [Three comments to the Olonets codex]. In Problemy Istorii $i$ Kul'tury Srednevekovogo Obshchestva. Materialy XXXVII Vserossijskoj Mezhvuzovskoj Konferencii Studentov, Aspirantov i Molodyh Uchenyh «Kurbatovskie Chteniya» (27-30 noyabrya 2017 g. Sankt-Peterburg: Skifiya-print SPB, pp. 139-44.

Alekseeva, Alina S. 2019. O protografe Oloneckogo sbornika [About the protograph of the Olonets codex]. In Tekstologiya $i$ IstorikoLiteraturnyj Process. Moscow: Buki Vedi, vol. 7, pp. 11-21.

Alekseeva, Alina S. 2020. Russkoyazychnye teksty Oloneckogo sbornika: Fonetika i grammatika [Russian texts of the Olonets codex: Phonetics and grammatics]. Russkij Yazyk v Nauchnom Osveshchenii 2: 128-50.

Alekseeva, Alina S., and Aleksei A. Gippius. 2019. Nabliudeniia nad tekstom Olonetskogo sbornika zagovorov. [Some observations on text of olonetskii sbornik]. Drevniaia Rus'. Voprosy Medievistiki 2: 141-57.

Allan, Keith. 2018a. Taboo words and language: An overview. In The Oxford Handbook of Taboo Words and Language. Edited by Keith Allan. Oxford: Oxford University Press, pp. 1-27.

Allan, Keith, ed. 2018b. The Oxford Handbook of Taboo Words and Language. Oxford: Oxford University Press.

Arkhipov, Andrei A. 1980. O proishozhdenii drevneslavyanskoy taynopisi. [About the origin of ancient Slavic cryptography]. Sovetskoye Slavyanovedeniye 6: 79-86.

Arkhipov, Andrei A. 1995. Po tu Storonu Sambationa: Etiudy o Russko-Evreiskikh Kul'turnykh, Iazykovykh i Literaturnykh Kontaktakh v X-XVI Vekakh. [Beyond the Sambation: Studies of Russian-Jewish cultural, linguistic and literary contacts in the X-XVI centuries]. Oakland: Berkeley Slavic Specialties.

Berezovich, Yelena L., and Svetlana M. Tolstaya. 2012. Tabu yazykovoe. [Tabu of words]. In Slavyanskie drevnosti: Etnolingvisticheskij slovar' $v 5 t$. Edited by N. I. Tolstoy. Moscow: Mezhdunarodnye otnosheniya, vol. 5, pp. 224-28.

Bulanin, Dmitrii M. 2020. Tajnopisanie i inopisanie (Novacii russkoj pis'mennosti v poru Vtorogo yuzhnoslavyanskogo vliyaniya). [Cryptography and alternative writing systems (inopisanie) (Innovations of Russian Literature at the Time of the Second South Slavic Influence)]. Palaeobulgarica/Starobulgaristika 3: 58-80.

DTYuS. 1998. Dejstvuyushchij travnik iz Yuzhnoj Sibiri. [Acting herbal from South Siberia]. Podgot. teksta, predisl., slovnik V.A. Lipinskoj, G.A. Leont'evoj. In Tradicionnyj opyt Prirodopol'zovaniya v Rossii. Edited by L. V. Danilova and A. K. Sokolov. Moscow: Nauka, pp. 414-479.

Frazer, Sir James G. 1888. Taboo. In Encyclopaedia Britannica, 9th ed. Edinburgh: A. and C. Black, vol. 23, pp. 15-18.

Frazer, Sir James G. 1911. The Golden Bough. Pt. 2: Taboo and The Perils of the Soul, 3rd ed. London: Macmillan.

Ippolitova, Aleksandra B. 2008. Russkie Rukopisnye Travniki XVII-XVIII Vekov: Issledovanie Fol'klora i Etnobotaniki [Russian Herbal Manuscripts of the Seventeenth-Eighteenth Centuries: Research in Folklore and Ethnobotany]. Moscow: Indrik.

Ippolitova, Aleksandra B. 2018. Legenda o trave s otkushennym kornem v russkoj rukopisnoj tradicii XVI-XIX vv. [The Legend of Grass with a Bitten Root in the Russian Manuscript Tradition of the XVI-XX centuries]. Zhivaya Starina 1: 6-10.

Kivelson, Valerie. 2013. Desperate Magic: The Moral Economy of Witchcraft in Seventeenth-Century Russia. Ithaca and London: Cornell University Press.

Láng, Benedek. 2015. Ciphers in Magic: Techniques of Revelation and Concealment. Magic, Ritual, and Witchcraft 10: 125-41. [CrossRef]

Láng, Benedek. 2018. Real Life Cryptology. Amsterdam: Amsterdam University Press. [CrossRef] 
Lavrov, Aleksandr S. 2000. Koldovstvo i Religiia v Rossii: 1700-1740 gg. [Witchcraft and Religion in Russia: 1700-1740]. Moscow: Drevlekhranilishche.

Levkievskaya, Yelena Ye. 2002. Slavianskiy Obereg. Semantika i Struktura. [Slavic Protective Magic. Semantics and Structure]. Moscow: Indrik.

Lukin, Pavel V. 2000. Narodnye Predstavleniya o Gosudarstvennoj Vlasti v Rossii XVII veka. [The Popular Political Beliefs in the 17th Century Russia]. Moscow: Nauka.

Malinovsky, Lev L. 1875-1876. Zagovory i Slova, po Rukopisi XVIII Veka. [Charms and Words, According to the Manuscript of the XVIII Century]. In Oloneckij sbornik. Petrozavodsk: Izd. Olonec. Gubern. Stat. Komiteta, vol. 1, pp. 69-92.

Malinovsky, Lev L. 1876. Zagovory i slova, po rukopisi XVIII veka. [Charms and words, according to the manuscript of the XVIII century]. Oloneckie gubernskie vedomosti. 1876. 28 fevr. No 15. pp. 161-63; 3 marta. No 16. pp. 172-73; 10 marta. No 18. pp. 192-95. Available online: https: / /ogv.karelia.ru/catalog.shtml?year=1876 (accessed on 2 May 2021).

Mihajlova, Tatiana V. 2003. Koldovskie Processy v Rossii: Oficial'naya Ideologiya i Praktiki Narodnoj Religioznosti (1740-1801 gg.). [Witchcraft Processes in Russia: The Official Ideology and Practices of Folk Religiosity (1740-1801).]. Diss ... kand. istorich. nauk. Sankt-Petersburg: Evropejskij Universitet.

Mihajlova, Tatiana V. 2018. Ot Kolduna do Sharlatana. Koldovskie Processy v Rossijskoj Imperii XVIII veka (1740-1800). [From Sorcerer to Charlatan. Witchcraft Processes in the Russian Empire of the XVII Century (1740-1800)]. Sankt-Petersburg: Evropejskij Universitet.

Müller, Stephan. 2014. Warum mittelalterliche Geheimschriften keine Geheimschriften sind. In Schriftträger-Textträger. Edited by Annette Kehnel and Diamantis Panagiotopoulos. Berlin, München and Boston: De Gruyter, pp. 169-78. [CrossRef]

Pushkarev, Lev N. 1977. Drevnerusskij lechebnik. [Old Russian medical book]. In Redkie Istochniki po Istorii Rossii. Edited by A. A. Novosel'ski and L. N. Pushkarev. Moscow: Iinstitut istorii SSSR AN SSSR.

Radcliffe-Brown, Alfred R. 1939. Taboo. Cambridge: Cambridge University Press.

RZRI. 2010. Russkie Zagovory iz Rukopisnykh Istochnikov XVII-Pervoi Poloviny XIX v. [Russian Charms from Handwritten Sources of the XVII-The First Half XIX Century]. Edited by A. L. Toporkov. Moscow: Indrik.

Sapozhnikova, Olga S. 2016. Neizvestnyj russkij perevod XVI veka iz mediko-astrologicheskogo traktata «Kniga o zhizni» ital'yanskogo gumanista Marsilio Fichino. [Unknown Russian translation of the XVI century from the medical-astrological treatise "The Book of Life" by the Italian humanist Marsilio Ficino]. Peterburgskaya Bibliotechnaya Shkola. 3: 12-24.

Sapozhnikova, Olga S. 2019. Evropejskoe izdanie epohi Vozrozhdeniya (Liber de arte distillandi): Prichiny izbiratel'nosti russkogo perevoda [Renaissance European edition (Liber de arte distillandi): Reasons of the selectivity of the Russian translation]. Drevniaia Rus'. Voprosy Medievistiki 4: 175-93.

Shchepanskaia, Tatiana B. 2001. Muzhskaya magiya i status specialista (po materialam russkoj derevni konca XIX-XX vv). [Male magic and the status of a specialist (based on materials from a Russian village at the end of the 19th-20th centuries)]. In Muzhskoj sbornik. Edited by I. A. Morozov and S. P. Bushkevich. Moscow: Labirint, vol. 1, pp. 9-27.

Smilianskaya, Elena B. 2003. Volshebniki. Bogohul'niki. Eretiki. Narodnaya Religioznost' $i$ «Duhovnye Prestupleniya»v Rossii XVIII v. [Magicians. Blasphemers. Heretics. Popular Religiosity and "Spiritual Crimes" in Russia XVIII c.]. Moscow: Indrik.

Speransky, Mikhail N. 1929. Taynopis'v Yugo-Slavyanskih i Russkih Pamyatnikah pis'ma (=Entsiklopedia Slavyanskoy Filologii, 4.3). [Cryptography in South Slavic and Russian Monuments of Writing (=Encyclopedia of Slavic Philology, 4.3]. Leningrad: Izdatelstvo AN SSSR.

Sreznevsky, V. I. 1913. Opisanie Rukopisei i Knig, Sobrannykh v Olonetskom krae. [Description of Manuscripts and Books Collected in the Olonets Region]. Sankt-Petersburg: Tipografiia Imperatorskoi akademii nauk.

SRYa 18 veka. 2003. Slovar' Russkogo Yazyka 18 veka. [Dictionary of Russian Language of 18 Century]. 13. Sankt-Petersburg: Nauka.

Strakhova, Olga B. 1988. Fragmenty zagovorov i molitv v travnikah. [Fragments of charms and prayers in herbals]. In Etnolingvistika Teksta. Semiotika Malyh form Fol'klora. Tezisy i Predvaritel'nye Materialy k Simpoziumu. Moscow: Nauka, pp. 40-42.

Tolstaya, Svetlana M. 1999. Zagovory. [Incantations]. In Slavyanskie Drevnosti: Etnolingvisticheskij Slovar' $v 5 t$. Edited by N. I. Tolstoy. Moscow: Mezhdunarodnye Otnosheniya, vol. 2, pp. 239-44.

Toporkov, Andrei L. 2005. Zagovory v Russkoj Rukopisnoj Tradicii XV-XIX vv.: Istoriya, Simvolika, Poetika. [Charms in the Russian Handwritten Tradition of the XV-XX Centuries: History, Symbolism, Poetics]. Moscow: Indrik.

Toporkov, Andrei L. 2007. Nominaciya «car'» i personazhi-«cari»v russkih zagovorah XVII-XIX vv. [Nomination "tsar" (king) and characters-"tsars" (kings) in the Russian conspiracies of the XVII-XX centuries.]. Voprosy Onomastiki 4: 67-82.

Toporkov, Andrei L. 2018. Onomastikon Oloneckogo sbornika zagovorov XVII veka. [Proper Names in the 17th Century Olonets Codex of Verbal Charms]. Voprosy Onomastiki 2018: 115-33.

Turilov, Anatolii A. 1998. Narodnye pover'ya v russkih lechebnikah. [Folk beliefs in Russian medical books]. Zhivaya Starina 3: 33-36. Turilov, Anatolii A. 2002. Narodnye pover'ya v russkih lechebnikah. [Folk beliefs in Russian medical books]. In Otrechennoe Chtenie v Rossii XVII-XVIII Vekov. (Tradicionnaya duhovnaya kul'tura slavyan. Publikaciya tekstov). Edited by A. L. Toporkov and A. A. Turilov. Moscow: Indrik, pp. 367-75.

Turilov, Anatolii A., and Alexei V. Chernetsov. 2002a. Otrechennye verovaniya v russkoj rukopisnoj tradicii. [Renounced Beliefs in Russian Manuscript Tradition]. In Otrechennoe Chtenie v Rossii XVII-XVIII Vekov. (Tradicionnaya duhovnaya kul'tura slavyan. Publikaciya tekstov). Edited by A. L. Toporkov and A. A. Turilov. Moscow: Indrik, pp. 8-72. 
Turilov, Anatolii A., and Alexei V. Chernetsov. 2002b. Velikoustyuzhskij sbornik XVII v. [Veliky Ustyug charms collection of the XVII c.]. (Predislovie i publikaciya A.A. Turilova i A.V. Chernecova). In Otrechennoe Chtenie v Rossii XVII-XVIII Vekov. (Tradicionnaya duhovnaya kul'tura slavyan. Publikaciya tekstov). Edited by A. L. Toporkov and A. A. Turilov. Moscow: Indrik, pp. 177-224.

Uspensky, Boris A. 1998. Tsar' i Patriarch: Kharizma Vlasti v Rossii. [Tsar and Patriarch: The Charisma of Power in Russia]. Moscow: Yazyki slavianskoy kultury.

Vinogradov, Nikolai. 1909. Zagovory, Oberegi, Spasitel'nye Molitvy i Proch. [Verbal Charms, Saving Prayers, and So On]. Sankt-Petersburg: Tipografiya MPS, vol. 2.

Yudin, Aleksei V. 1997. Onomastikon Russkikh Zagvorov. [Onomasticon of Russian Incantations]. Moscow: MONF.

Zelenin, Dmitrii K. 1929. Tabu Slov u Narodov Vostochnoj Evropy i Severnoj Azii. [Taboos of Words among the Peoples of Eastern Europe and North Asia]. Leningrad: Izdatelstvo AN SSSR, vol. 1.

Zelenin, Dmitrii K. 1930. Tabu Slov u Narodov Vostochnoj Evropy i Severnoj Azii. [Taboos of Words among the Peoples of Eastern Europe and North Asia]. Leningrad: Izdatelstvo AN SSSR, vol. 2. 